\title{
Promoting Gender Inclusive Governance to Deliver Better Education in Nepal
}

\author{
Rebat Kumar Dhakal ${ }^{1}$ \\ ${ }^{1}$ Kathmandu University, School of Education, Lalitpur, Nepal \\ Correspondence: Rebat Kumar Dhakal, Kathmandu University, Lalitpur, Nepal. \\ Email: rebat@kusoed.edu.np
}

Received: June 20, $2019 \quad$ Accepted: August 19, $2019 \quad$ Online Published: September 1, 2019

doi: $10.23918 /$ ijsses.v6i1p83

\begin{abstract}
With inclusion agenda gaining currency in public policy discourse, women representation has now been ensured in public institutions, including schools, in Nepal. Informed by the concepts of representation and participation, this paper argues that though women's participation in decision-making has received significant attention across the world, there are less opportunities for female to engage in governance and decision-making in Nepali community schools. Against this backdrop, this paper aims to examine what perspectives School Management Committee (SMC) members hold towards inclusion of female members. Employing interview and observation techniques during six months of ethnographic fieldwork, I collected data from six members in the SMC (including three female) from a community secondary school in rural Kaski. The findings highlight some surfacing inclusion issues in school governance which are contestable. The study concludes that though descriptive representation of female is ensured, female are yet to ensure their substantive representation in the school board.
\end{abstract}

Keywords: Gender Inclusion, Participation, School Governance, Ethnography, School Management Committee

\section{Introduction}

The changing socio-political transformations in Nepal in the recent past have established several social agenda including inclusion (and exclusion) of different segments primarily based on caste, ethnicity, and gender, in the existing social institutions. More particularly, over the last two decades, the issue of inclusion has been on the rise in Nepal and many policy provisions (about women, dalits, adibasijanajatis, madheshis, downtrodden classes, etc.) have been made and put into effect. Considering gender and social inclusion as vital for securing inclusive development (Nazneen \& Mahmud, 2015), the Good Governance Act 2008, the Tenth Five year Plan 2002-2006, and the Constitution of Nepal 2015 all have addressed them in one way or the other. Likewise, different development partners such as UK Government's Department for International Development (DFID), World Bank, Asian Development Bank, European Union, Danish International Development Assistance (DANIDA) are also placing high importance on inclusive governance (Sigdel \& Sharma, 2013). In fact, inclusiveness is a core value of democratic governance which allows for equal participation, equal rights and treatment (Liyanage, 2018, p. 117). Inclusive governance implies bottom-up decision making, having all concerned stakeholders at every level of governance participate (Beall, 1996, p. 3).

In a school context, inclusive governance refers to the system and practice where the views of all school community (including parents and students) "shape decisions on school priorities, resources and activities" 
(Crowley, 2004, p. 16). Here, inclusive governance implies an institutional mechanism of giving access to participation for all school stakeholders including teachers, learners, parents, officials from education line agencies, community people from diverse background like gender, ethnicity, geography, physical condition among others without discrimination in overall school activities. In this connection, SMC members, and other school stakeholders including higher line authority, teachers, parents and students bear no less responsibility to improve school system and to promote inclusive and "participatory school governance" (Obondoh, Nandago, \& Otiende, 2005) to bring about overall school effectiveness. It is important to give men and women "space to voice their experiences and concerns" (Kwauk \& Bever, 2017) in regards to the decisions that impact their children's education.

In the education sector in general and in school governance in particular, some provisions are made, especially regarding female participation. For example, there should be at least one female teacher in the District Education Committee; at least three female social workers or educationists (also a person with disability) in the Municipal/Village Education Committee and at least three female members in the School Management Committee (Ministry of Education, 2016). This encouraged me to explore how our schools are promoting inclusive governance or better say, how inclusion is perceived and practiced in the context of school governance. My working definition of gender inclusive (school) governance is a process of increasing opportunities for participation of women in planning, organizing, leading and controlling of school affairs, enhancing their capabilities to fulfil normatively prescribed roles as SMC members, gaining social respect and recognition, and at the collective level, enhancing school community engagement and influencing school decisions (making processes).

In Nepal, education is a major concern of the community and their participation and involvement in school management is essential (Sharma, 2008, p. 73). This might be the reason for Local Self Governance Act (1999) to entrust the local Governments with the responsibility for initiating, developing and ensuring ECED services at village and municipal levels (Ministry of Law and Justice, 1999). Likewise, school management is a shared responsibility between school, community and local government (MOE, 2009). Since the thrust of the SSRP is to strengthen school based management, policy directives suggest increasing participation of local people in school management (cases of management transfer to communities since 2002). This process is believed to raise the participation of stakeholders, enable more realistic problem identification, and increase the efficiency of governance and management (MOE, 2009, p. xxxix). Likewise, the practices such as School Improvement Plan (SIP), Village Education Plan (VEP), District Education Plan (DEP) and Annual Strategic Implementation Plan (ASIP) introduced during the EFA implementation are also expected to contribute to an increased involvement of parents, teachers, students, local stakeholders, promoting inclusivity in school governance and management (MOE, 2009, p. xvii). The evidence presented above underscores the significance of continuing and promoting participation in school governance practice in Nepal. Today, more than ever, a number of interconnected factors argue for the necessity of participatory school governance.

As the most influential and active body of the school governance, it is important to see SMC in an organizational context in which the politics and economy besides sociology of human thinking affect how SMC members perceive themselves, and those they work with, as well as how other stakeholders perceive their roles. From here we also need to be able to understand the place of parents in wider socio-economic and political contexts, e.g. we need to know how certain management practices come about and constrain 
or enhance school governance. This way, the study will also contribute to build knowledge on the practices of school governance at the local level.

In general, the role of women in key decision making has largely been ignored in the past (Goodman \& Harrop, 2000). However, lately, women's participation in decision-making has received significant attention across the world. For example, SDG 5.5 commits women's "full and effective participation" in leadership at all levels of decision-making, and 16.7 commits responsive, inclusive, participatory, and representative decision-making at all levels (United Nations, 2015). In particular, changing socio-political dynamics in Nepal have also led to growing awareness of the importance of inclusive governance and given way for inclusion in public institutions. Education (8th amendment) Act provisions for an increase in the number of women in SMC in to ensure that schools are governed in a manner that reflects the inclusive ideology of the state (Ministry of Education, 2016). However, despite this enabling policy framework, the researchers' own experience as well as research findings (Goetz \& Nyamu-Musembi, 2008; Madlala, 2007; Schley \& Schratz, 2011) show that women in governing boards still experience a number of challenges in practice, as compared to their male counterparts, especially in the society which have historically been governed by patriarchy. As Sigdel and Sharma (2013) indicated, much has been done at the policy level, yet practice at the local institutional level has not got much attention. When we observe the education governance scenario, we can find different formal structural arrangements at the local level as well, which require some form of representation of different stakeholders. However, these formal structures may not be sufficient to ensure inclusive practices in schools. In this light, this paper argues that in the context where women's participation in decision-making has received significant attention across the world, there are less opportunities for female to engage in governance and decisionmaking in Nepali community school governance. My argument here is that parental participation has been framed almost exclusively in terms of fulfilling the legal requirements, and not necessarily to contribute to inclusive agenda of school reform.

It is against the above backdrop that this paper intends to explore the perceptions and practices of inclusive school governance, especially from the perspective of female (parent) inclusion. More particularly, it aims to examine how School Management Committee (SMC) members perceive inclusion of female members and how such inclusion promotes better educational outcomes.

\section{Research Design}

This ethnographic research study, conducted in Kaski Model School (a secondary school in rural Kaski) in Western Nepal, explores the perceptions of SMC members about the inclusion of female members in the SMC. The fieldwork for this study was conducted from April 2016 till August 2017. The data in the form of 'talks', 'texts', and 'interactions' (Silverman, 2006) on inclusive school governance practices with special focus on female members' representation and participation were derived from participant observation (in SMC formation meeting, teacher selection committee, donation acceptance and honouring the donor, and 3 other regular SMC meetings), field note-taking and open informal interviews (in 15 sittings) with my key participants. A purposive sample was deliberately selected to seek the insider perspectives of the SMC members themselves on the practice of gender inclusion in the SMC. The sample consisted of six members from the SMC [Chair (1), Headteacher (1), male member (1 female) and female members (3). By the time I selected the research participants, I had been to the school several times and got good familiarity with almost all teachers and some members of the SMC (in fact, I also had good 
familiarity with some members from the earlier SMC because my site visit had already begun before the new SMC was formed).

Participants were interviewed individually at their own convenience for both time and place, but most of them preferred school set up, rather than their own residence. However, two rounds of interviews with the female members alone were conducted in groups. During the entire process of this research, including at the field with the participants, all ethical considerations were taken into consideration. I fear if I could really interpret the female voice the way they mean - because my macho subjectivity may sometimes come up to the surface. I think there might be different kind of interpretations if the same texts (of female voices) are interpreted by a female researcher. I therefore aware my readers to take my interpretation as one made from a male perspective. In terms of data analysis, interviews were recorded and transcribed while the research questions provided the analytical background against which data were interpreted and classified. The data for the strand of analysis reported in this paper were classified in accordance with the following thematic units divided into episodic presentation: (1) understandings of inclusive school governance discourse and (2) Enactments of and perspectives on gender inclusion in school governance.

\section{Understandings and Enactments of Inclusive School Governance Discourse}

Here, I develop a conversational presentation of my field data in two episodes by stitching the scattered texts and talks drawn from the informal one-on-one and group interactions. Episode I is focused on narrating the participants' understanding of 'inclusive governance' of school, and Episode II is more focused on the perceptions and beliefs that the SMC members held about gender inclusion in the SMC.

\subsection{Episode I: Understandings of Inclusive School Governance Discourse}

I: $\quad$ Namaste! Before I ask you any questions, let me explain what the discussion will be around. .... Our discussion today will focus on the perceptions of SMC members towards gender inclusion in SMC. Now, let me begin our interaction with a common question to you all: what do you mean by inclusive nature of SMC? First, SMC Chair!

Milan Sir: $\quad$ For me, having the representative from different segments of the society in school decision making - it is the right representation of the society in school governance.

I: $\quad$ Do you mean equal participation of different stakeholders in the decision making process?

Milan Sir: $\quad$ Yes, but frankly speaking. Most of the time, the Member Secretary (HT) is sufficient in making key decisions...we are there to support him. Because in my experience, he is often able to convince other members. After all, he is the one who is very close to school and knows the everyday needs of school.

I: $\quad$ Hajuraama, what do you say?

Hajuraama: $\quad$ Inclusion has to do with giving chance to all members of the society, not literally all, but a good representation of all kinds of people, including women, Dalits, Janajatis, etc. I also think that there should have been students also in the SMC.

(Hajuraama further gives an anecdotal evidence based on her experience in the previous SMC to highlight why student representative should also be in the SMC.) (I could see other members nodding their heads in agreement with Hajuraama's remarks.) 
I also agree with Milan Sir in that our role as SMC members is that of trustees who do not encroach on the strategic moves the HT takes. ... He is also my grandson (HT). He sometimes informs me what he is doing and how he is doing it. He also tells me what I should do and sometimes also what to say - when.

(I wonder why Hajuraama seems to be in dilemma about her role; in one hand she thinks of also including students, on the other, she presents herself (intentionally) powerless and not willing to participate fully).

I:

Sharma Ji, your idea?

Sharma Ji: (crossed his legs and puts his one hand on the arm of the chair and another on the nearby chair) $I$ think that having the right representation of different groups as provisioned in the education act is what inclusion in school governance all about; and this is what we have been practising. Earlier there was only one female, now we have three, by this we have become more inclusive in terms of gender.

As far as having students in the SMC is concerned, Hajuraama raised a valid point I think. I personally agree with Hajuraama and think that it might be possible to replace two members with students in the current provisions. Though we cannot go against the policy provision and replace some members with students now, we have some mechanism to listen to our students' views in the decisions which impact them. (He also sheds light on how they respect students' voice.)

I: $\quad$ Thuldai, how do you see 'inclusive' SMC?

Thuldai: $\quad$ By the current practice, I understand 'inclusive SMC' as having the presence of more female members.

I: $\quad$ What do you mean by current practice?

Thuldai: $\quad$ It means the recent changes in the policy of SMC formation and having three female members.

(I reckon that Sharma Ji and Thuldai were more concerned about meeting the policy requirements.)

I:

Do you have any comments on this provision?

Thuldai: $\quad$ I personally think that the policy of including female members is not bad; but the scenario in our community is that women do not easily come up; they have more household chores and they cannot give much time to the school. Besides, they also somehow lack knowledge of the way school runs. It takes time for them to understand the school context, and by the time they know the school dynamics, their tenure will be over. I think we need women who better understand school affairs in the school boards.

I: $\quad$ SharmilaBhauju, may I get your response on what makes your SMC inclusive?

SharmilaBhauju: The fact that it gives space for the involvement of the 'other half' (women) makes it inclusive. There could be other things as well to make it more inclusive, now our SMC has a good gender inclusion as it includes three women.

I: $\quad$ Milan Sir, can you once summarise this discussion and put forth your ideas if any?

Milan Sir: $\quad$ To make our school governance inclusive, we have to have the real presence and active participation of diverse people and minds in our SMC and PTA. Though I do not neglect the presence of diverse people, I focus that what expertise and skills each individual brings in is more important. This may sound more idealistic but inclusion if it is to be ensured should focus on the right mix of abilities and expertise in the members that govern school. I therefore sometimes feel that current issue of inclusion itself if very superficial. 
Inclusion by gender, caste is nonsense - can't a Gurung represent a Brahmin and can't a nondalit speak the voice of dalits? For me, inclusion should have been in terms of the diversity of knowledge, skills and attitude each member bring to the school board, rather than mere identity as a female or a Janajati. I also believe that a single person can be inclusive in terms of speaking up their voice - this is the norm of democracy that one person represents the group.

TikaBhauju: $\quad$ Yes, I partly agree with what Milan Sir said, but at the initial stage of representing diverse group's voice, it is important that we include the diverse groups themselves because we are yet not ready for professional inclusion. Once we develop the professional competence, we should think of having professional inclusion as well.

Inclusion is about our right as women - we have the equal right or even designated quota to participate in all public institutions. This is for fairness and equality.

The episode reflects the perceptions of SMC members about inclusive governance in school. Though a commonly agreed meaning could not be drawn, the message of inclusion was somehow perceived to be including the diverse social members who are considered school stakeholders in the mechanism which makes school based policies and decisions, and in special reference to this study context, I could draw that having the female representatives who would bring in the voice of the parents in general and of female community members and girl students in particular in the course of making decisions in school. Although there was a temptation in my participants to have every school stakeholders' representative in the school board to call it 'inclusive', by virtue of being overly crowded, democratic practices prefer a small number of representatives and delegates the power therein (Halpin, 2010). Moreover, inclusion is also context specific (Silver, 2015) - though inclusion of many stakeholders including students is probably a desirable aim, the context of inclusion in current SMC according to the provision of the Education Act allows for only nine members to be on board, and school boards cannot modify this policy at the local level at their discretion.

As it occurred to my mind, male members often referred to the "inclusion" of female in the SMC as their "presence" or "representation" and "fulfilling the legal provision", while female members were more inclined to understand their involvement in the SMC as their right (to maintain fairness and equality in society), and also identity of being women and thereby representing the 'other half' of the school community. I came to know that the female participants preferred using the term 'other half' because that particular segment of the society was made 'other' and thus was almost excluded in the previous SMCs. In this way, female members tended to consider this policy shift in response to social exclusion they have faced in the past. However, I could not observe any reaction or counter expressions in other members' face while Hajuraama was expressing her intentional powerlessness and less active participation in the SMC. She further attributed this situation to have resulted out of strong trust on the HT, which was in turn caused due to her family relations with him. It was natural that the implementing duty of the decisions made by the SMC falls on the HT's shoulders. But based primarily on the strong trust of Hajuraama on the HT (because he was her grandson), and also on the Chair (because he was her nephew), it was important to also see participants' social positioning and relations. Rather than professional roles, they were often more family like in the school premises and also in the SMC meetings. Social positioning and school connectedness of other members will be discussed in the following episode. 


\subsection{Episode II: Enactments of and Perceptions on Gender Inclusion}

I:

Hajuraama,

Hajuraama:

I:

Hajuraama:

I:

TikaBhauju:
Namaste! In this session, we will discuss the enactment of inclusive governance practices in your school.

what difference do you find between the past SMCs and the present one?

Pretty much, the meetings are more regular, and most of the members are present. And this one is more open.

Open in what sense?

Open means participatory! They ask for our opinions and we can also put our opinions more freely. Earlier, the HT and the Chair would only sit together and in the meeting, they would tell us the decision and ask us to sign. Now, they have a formal procedure. Inform us of the agenda, and discuss on the agenda one after the other and make decisions there. This grandson of mine also listens to our voice. Unlike the earlier practice, we now do not sign the minutes if we are absent.

Earlier I used to be the only woman, and would feel uneasy to speak up, but now I have two ladies, and I do not feel alienated.

TikaBhauju, what is your opinion?

It is true that sometimes when other two female members do not turn up in time, I do not feel at home, and I feel relieved when I see them.

SharmilaBhauju: (interrupts TikaBhauju) Though it has only been a one day incidence that I attended the meeting at the status of just one women, but I like to be in women's group.

... Also because there is no designated seat and room for our meeting, and I have to go to the Headsir's office, and there are other teachers also. I don't want to disturb them with my presence. If only we (all SMC members) had a separate room and chairs, coming to school even when there is no meeting would be easier.

(The boardroom dynamics also shows that female members tend to sit together. My observation of five SMC meetings showed that except for one day when TikaBhauju arrived late, women formed their group and sat together at one side. On the day TikaBhauju arrived late, she was asked to take a seat nearby the SMC Chair, which was near the entrance.)

I:

I am fortunate that whenever I come to your school and participate in your meetings, all female members are present (one or the other male member was absent though). TikaBhauju, is there any reason or is it only a co-incidence?

TikaBhauju: $\quad$ Head Sir also says that we (women) are always punctual and we are mostly regular. But Head Sir also tells us about when you are coming, he insists that we must be present because you want to talk to us, don't you?

I: (With some light jokes, I change the topic. I navigate the discussion towards the competence, roles and engagement of SMC members)... What is the advantage of having more female members on board?

Milan Sir: $\quad$ Gender inclusion has brought about system-level reform and policy change to address inequities in school governance. Earlier we used to have only one woman and she seemed to be powerless, now they have got collective power. And that they can speak up. With more female members, I have found that they feel empowered, they have started some gender initiatives for girls.

I: What roles do you think are important ones for the SMC members? 
Hajuraama: $\quad$ From my experience I can tell you that our major roles are attending meetings, supporting the HT to make school policies to ensure good culture of teaching and learning, and managing school finances and procurement. But I think school personnel (HT and Accountant) should deal with the finance and procurement, and teachers and Headteachers better how to teach and what to teach. We leave these areas for them. But when we hear any complaints against any teacher's behavior or way of teaching, we raise the matter in the meeting. We have informally given full authority to the Headteacher about pedagogical matters and students' discipline.

SharmilaBhauju: (raises her hand and interrupts Hajuraama) Oh, in one instance, let me share it. The Headteacher and teachers had expelled a student who was caught in some indecent act (caught with cigarettes, consuming cannabis and was acting badly - mistreating the girls in his class, and also spoke rudely with a teacher). But the SMC members, after appeal by the students' parents, thought that the HT made a wrong decision without their consent. And the SMC alleged that the HT was becoming super-powerful. Though there was a kind of conflict between the SMC and the HT for some time, I personally feel that what the HT did was right. I also know that boy very well, if he was kept in school, he would one day definitely spoil the school's image.

I: $\quad$ Do you have any particular area of interests in school activities?

TikaBhauju: $\quad$ Though we do not have any designated sector to look at, I find school-community relations as my own area of interest. I also feel particularly interested in girl children in school. To be practical and to say it frankly, we have strong trust on the HT and teachers and that we do not interfere with the teaching learning matters. Whatever plans they come up with that is considered good, we approve them, including coaching and tuition classes, dayboarders' facility for SEE, grade 11 and 12 students and tuition fees.

SharmilaBhauju: We are only members, who listens? So we rather keep quiet. We also don't know much about school business about teacher training, classroom management, curriculum. So sometimes we feel to be 'outsiders' to school.

I: $\quad$ Hajuraama, do you also feel like that? What makes you feel like that?

Hajuraama: I think 'outsider' means our roles sometimes in the SMC is not important because they discuss teacher issues, teaching learning issues. And there we do not have much to contribute to the discussion.

TikaBhauju: $\quad$ Sometimes, not having some previous exposure to school jobs and not knowing the school affairs and relations with higher authorities make us feel incompetent and outsiders. I think slowly this gap will erase. But we should also be proud of what we could have done. We have been successful in bringing some gender based reforms.

I: $\quad$ What kind of?

TikaBhauju: I think this case makes inclusion an important policy. Through our collective voice, we could manage sanitary pads for the girls and its disposal system. If we were not in the board, I think this would not have happened. We started raising funds by inviting the teachers and students to donate some at their will to the 'school fund' on their bornday. Now no chocolates are distributed, but the birthday boy/girl will donate some money to the fund. And parents are also happy about it. We have also formed a Girls' Club.

Sharma Ji: In our context, mothers generally know much more than fathers about their kid's schooling activities and needs. And they know it better when it comes to girl children. I feel that gender inclusive SMC has enabled us to implement gender sensitive reforms. Moreover, girls' attendance, confidence and participation has increased. You can see now many clubs being led by girls.

I: $\quad$ How have you found working with female members? Is it comfortable or challenging? 
Milan Sir: $\quad$ Female often probe deeply and get deep down the roots of the issues, but that is sometimes irritating...explaining to them everything in detail. But one important shift in the current SMC is that the members are more regular and female are even more regular and punctual.

I: $\quad$ Thuldai, you mentioned in the last episode that women lack necessary knowledge of school affairs, on what basis did you make this claim?

Thuldai: $\quad$ I mean, it is true that they know the seen activities, but there are many unseen business...dealing with District Office, RP, local political leaders, donor agencies, managing financial burden. They (referring to the present female members) hardly have any idea.

I: (I got more interested in understanding this, and turned to the Headteacher.) Sharma Ji, do you agree with Thuldai?

Sharma Ji: It is true, but it is not the only reality. It is also true that some male members also do not know much about school business, and their participation is quite the same as that of female members.

I: $\quad$ Shall I ask if people's perceptions of you (female member) changed when you became a member of the SMC?

SharmilaBhauju: Many people, including school teachers, see us as women, not SMC members. Therefore, gender based discriminatory conservative practice still persists. This is even more challenging for us because all of the women in our SMC have come from non-school background (none of us have experience of working in schools). If only we were teachers earlier, I am sure, their perceptions would be different. (Early day of her SMC membership position)

Now I think we are respected; everybody knows us. Self-esteem has increased, I feel empowered. Many community people consider me to be an ideal person - who is in charge of the school that educates their children. Many children also share their problems and good feelings in school. (Later day of her SMC membership position)

Earlier we were sometimes tagged as 'quota woman' and nobody liked to be a 'quota woman'. But now, that does not matter. What matters is whether we can speak up for the common good of the school, of the girls, and of our children.

I: Is there any positive influence on children or community due to your participation in the SMC?

Sharmila Bhauju: I have found that my daughter is doing better and she is happier since I became the SMC member. My neighbours tell me that their kids are also doing better. It shows that where mothers are involved in their school, children do better and are happier.

In this episode, I knew that there were diverse views on inclusion of female members in the SMC - in relation to their roles, school engagement, and influence. From the interaction it emerged that female members regarded HT and teachers as persons who should deal with school finances and matters of procurement. They did not know what pedagogical policies the school must adopt and therefore they regarded this as something that is better known by the (head)teachers. In this sense, they seem to have given full authority and autonomy to the Headteacher and teachers in matters of pedagogical innovations and curricular practice. One important construct that appeared during the discussion was how female members feel marginalized and alienated if they have to miss other female members in the meetings. Though the perceptions towards female members in the SMC has changed radically from the past, women still shy away from owing the school - they feel uneasy stepping into the Headteacher's office, and finding no designated room and chair for them. 
In terms of the level of participation, women feel that current SMC meetings (in comparison to the past ones) are more open and democratic in that the Chair and the HT listen to their voices. They rather ask for female members' opinions. However, SharmilaBhauju's remarks "We are only members, who listens?" and that they do not know much of school business make their status as 'outsiders' - who have little knowledge of the school affairs, have no relational link with education line agencies, and thus little to say in the meetings. It occurred to me that the present challenge is whether women in the school board, over time, lose their outsider status and participate fully - ensuring their substantive representation (Phillips, 1995; Pitkin, 1967). In the initial days, they also wished that they had had some previous exposure to working in a school. Had they gained such experience as teachers or administrators in a school or other social institution or held any positions in some public service earlier, they thought that the male perception of women "as women" and not "SMC members" would have been different. However, later they found themselves more cognizant of the school affairs or at least created their own spaces by looking into some sectoral issues including gender, girl children, school community relations, etc. They take pride in having been successful to implement some reforms for girls - management of sanitary pads and its disposal system, formation of Girls' Club and its meetings and activities. Moreover, due to the presence of more female members, as agreed by male members too, girls' attendance, confidence and participation in different activities have increased. In addition, male members also praised female members for starting to make a positive impact on the lives of girls, and have influenced the society positively. As such inclusion has ensured that educational stakeholders accept, respect, and value differences (Virginia Center for Inclusive Communities, n.d.) - developing strategies for creating more supportive learning environments and thereby delivering better educational outcomes. At this juncture, I reckon that education stakeholders tend to forget that teachers and members of the SMC themselves are gendered beings and can carry with them the gender norms "baggage" of their communities (Kwauk \& Bever, 2017). Therefore, if we tend to focus on strategies for enhancing inclusive education, we first need to focus on strategies for changing the gender norms and attitudes of teachers and school board members.

Like some male members women members were also considered less skilled, lacking knowledge of school affairs and contributing not much in the meetings - rather prolonging the decision making process as they needed more explanations to understand the dynamics of the decisions. This evidence contributes to verifying the claim that though "descriptive representation" (Pande \& Ford, 2011; Pitkin, 1967) is ensured, women are yet to ensure their substantive participation in the school governance. Pitkin (1967) characterizes descriptive representation as the extent to which a representative resembles those they are representing. Earlier, there was a hidden feeling that female were bothered about - to be a 'quota woman' which had a negative connotation that they got to the position by chance not by choice, that they got into the position though they were not as capable as other competitors from the opposite gender. But later, the so called 'stigma of becoming a quota woman' eroded as they could make some positive impact on girls' education, awareness and participation.

Although the majority of the members felt that they approve the HT's decisions regarding student disciplinary matters, the SMC did not always like the HT's single decision to expel a learner. This indicates that the conflict of roles exists between the SMC and the HT. This finding confirms that power relations affect school governance. Deem, Brehony, and Heath (1995) also contended that "power relations are central to any understanding of the practices and processes of school governance, regardless of the cultural context in which they operate" (as cited in Mncube, 2009, p. 94). While not many power struggles were 
noted and observed, it was noted that participation of (female) members was hindered by power relations, as in some cases decisions were taken by the HT (sometimes in consultation with one or two SMC members, or only with teachers) instead of the full SMC. In an instance of conflict, a member even accused the HT to have been trying to be super-powerful.

The belief that women are often caught in the middle of having to balance domestic chores (being mothers and wives) and work (as members of SMC) responsibility, and thus they may slack in their work responsibility as leaders, was held by both male and female participants. But I found this belief challenged in my research context and I found enabling home environment in case of two female members. In fact, one was often pushed by their family (as she herself, her husband and her father-in-law all reported in different conversations) to prioritize school related work, the other one was an elderly woman who did not have much family obligations and had found visiting school as a good pastime - as she reported "Even if I was not a member, I would often visit the school because this is my courtyard." Whereas, my third female participant faced some difficulty in the beginning because of her family reason - her husband did not like the idea of his wife becoming the SMC member and giving some time to school because she was already busy in a Cooperative also. Since her job at the Cooperative was pretty flexible, she could easily make time for school visits - besides the distance between the Cooperative and the school was merely 500 meters. Unlike the popular belief and some research evidence, women often turned out to be more punctual and regular to the SMC meetings.

\section{Conclusion}

The message of inclusion is simple: including all relevant stakeholders in mainstream leadership of a school, and my participants in this study context understood inclusion as representation or presence of female members in the school governance body, i.e. SMC. It was as simple as that! However, there were sharp lines of contrasts in both understandings and in practices. Therefore, I found the idea of inclusion contestable in my field. At one end, participants reflected that the current kind of inclusion is superficial and does not contribute much to improve school effectiveness. At the other end, they themselves also reflected that current inclusive governance practice is the result of some systemic and programmatic reforms. While representation and deliberations are theoretically open and fair, there are still factors like their lack of knowledge of school affairs that limit female SMC members from participating fully in issues of school governance. Moreover, women still seemed to have 'outsider' status to the school board and that they often 'nodded' their heads during the SMC meetings. Moreover, their seeming ignorance of school affairs and strong trust on the HT and Chair made them 'alienated' and 'excluded' in the decision making process. This creates space for the Education Governors to empower and equip local school governors with necessary knowledge and skills through concentrated training packages so that their meaningful participation could be ensured. Moreover, in order to accentuate female participation, presence of at least two women is desirable in each SMC meeting against the existing quorum based decision-making with no reference to female members. As the paper argues in the beginning, it also concludes by restating that though descriptive representation is ensured, female are yet to ensure their substantive participation in the school board. 
International Journal of Social Sciences \& Educational Studies ISSN 2520-0968 (Online), ISSN 2409-1294 (Print), September 2019, Vol.6, No.1

\section{References}

Beall, J. (1996). Urban governance: Why gender matters (UNDP Gender in Development Monograph Series, No 1). New York, NY: United Nations Development Programme (UNDP). Retrieved from https://www.gdrc.org/u-gov/doc-whygendermatters.html

Crowley, N. (2004). Meeting the inclusive challenge. In The inclusive school (pp. 12-20). Limerick, Ireland: Irish National Teachers' Organization and the Equality Authority.

Goetz, A. M., \& Nyamu-Musembi, C. (2008). Voice and women's empowerment: Mapping a research agenda (Pathways Brief No. 2). Brighton, England: Pathways of Women's Empowerment.

Goodman, J., \& Harrop, S. (2000). Women, educational policy-making and administration in England: Authoritative women since 1880. London, England: Routledge.

Halpin, D. R. (2010). Groups, representation and democracy: Between promise and practice. Manchester, England: Manchester University Press.

Kwauk, C., \& Bever, S. (2017, November 2). How can teachers be more gender inclusive in the classrooms? Retrieved from https://www.brookings.edu/blog/education-plusdevelopment/2017/11/02/how-can-teachers-be-more-gender-inclusive-in-the-classroom/

Liyanage, K. (2018). Gender inclusive governance: Representation of women in national and provincial political bodies in Sri Lanka. In A. Ahmed (Ed.), Women in governing institutions in South Asia: Parliament, Civil Service and local government (pp. 117-137). London, England: Palgrave Macmillan.

Madlala, N. C. (2007). Challenges facing women in management: Perceptions of school level women managers in Ogwini Ward of Port Shepstone (Unpublished master's dissertation). University of KwaZulu-Natal, Durban.

Ministry of Education.(2016). Education (8th amendment )act 2016. Kathmandu, Nepal: Author.

Mncube, V. (2009). The perceptions of parents of their role in the democratic governance of schools in South Africa: Are they on board? South African Journal of Education, 29, 83-103. Retrieved from http://www.sajournalofeducation.co.za/index.php/saje/article/viewFile/231/138

Nazneen, S., \& Mahmud, S. (2015). The gendered politics of securing inclusive development. In S. Hickey, K. Sen, \& B. Bukenya (Eds.), The politics of inclusive development: Interrogating the evidence (pp. 197-230). Oxford, England: Oxford University Press.

Obondoh, A., Nandago, M., \&Otiende, E. (2005). Managing our schools today: A practical guide to participatory school governance. Bamako, Mali: Pamoja.

Pande, R., \& Ford, D. (2011). Gender and quotas and female leadership: A review (Background Paper for the World Development Report on Gender). Retrieved from http://siteresources.worldbank.org/INTWDR2012/Resources/77781051299699968583/7786210-1322671773271/Pande-Gender-Quotas-April-2011.pdf

Phillips, A. (1995). The politics of presence. Oxford, England: Oxford University Press.

Pitkin, H. F. (1967). The concept of representation. Berkeley, CA: University of California Press.

Schley, W., \& Schratz, M. (2011). Developing leaders, building networks, changing schools through system leadership. In T. Townsend \& J. MacBeath (Eds.), International handbook of leadership for learning (pp. 267-296). London, England: Springer.

Sharma, T. N. (2008). Structures and mechanisms of community participation in school management. Journal of Education and Research, 1(1), 72-85.

Sigdel, S., \& Sharma, S. S. (2013). Inclusive governance (Policy Brief). Kathmandu, Nepal: UKAid. Retrieved from http://www.edgroup.com.au/wp-content/uploads/2014/03/ESP-IG-PolicyBrief-Final.pdf

Silver, H. (2015). The contexts of social inclusion (DESA Working Paper No. 144). New York, NY: United Nations Department of Economic and Social Affairs.

Silverman, D. (2006). Interpreting qualitative data: Methods for analyzing talk, text, and interaction (3rd ed.). Thousand Oaks, CA: Sage. 
International Journal of Social Sciences \& Educational Studies ISSN 2520-0968 (Online), ISSN 2409-1294 (Print), September 2019, Vol.6, No.1

United Nations. (2015). Transforming our world: The 2030 agenda for sustainable development. New York, NY: Author.

Virginia Center for Inclusive Communities. (n.d.). Mission, vision, and core values. Retrieved from http://www.inclusiveva.org/aboutus/mission/ 